\title{
Public Health Communication in France during the Spanish Flu and the COVID-19 Pandemic: The Role of Experts
}

Klara Dankova

Università Cattolica del Sacro Cuore, Milan, Italy

\section{Abstract}

In times of crisis, a government's communication with the public is fundamental, as one of the government's main tasks is to provide critical information to protect the population. In the current context of the COVID-19 pandemic, public health communication has been paramount because of the elevated risk of contagion. Moreover, in public health communication, experts play a pivotal role by providing reliable information on the basis of their technical expertise. The impact of the COVID-19 pandemic is often compared to that of the Spanish flu, a pandemic occurring in 1918-1919, whose global spread decimated tens of millions of people. This contribution aims to assess the role of experts in the two crises by highlighting the differences in France's public health communication during the two events. Assuming that the objectives of public health communication during the two pandemics were more or less identical, i.e. to prevent the spread of disease and inform and protect the public, the paper inquires about the means used to achieve them, focusing on the contribution of experts. The main characteristics of public health communication during the Spanish flu will be investigated by analysing articles published in the period between 1918 and 1919 in two French newspapers Le Matin and Le Petit Parisien. In terms of the current COVID-19 pandemic, this paper will probe articles published since December 2019 in the newspaper Le Monde.

Keywords: public health communication, expert, pandemic, COVID-19, Spanish flu

\section{Introduction}

The serious pandemic situation brought about by the spread of COVID-19 has highlighted the crucial role of public health communication in state crisis management. In this context, only clear and precise communication can provide useful information to protect the public and consequently limit the spread of the contagion as much as possible. The provision of up-to-date information on the development of the epidemic, alongside scientifically based prognoses on the probable development of the crisis, provides the public with valuable and useful information for planning their future actions. Finally, another important function of public health communication is to reassure the public of the measures taken to ensure 
their safety and thus avoid situations of confusion and panic. To achieve these objectives, experts play a significant role in public health communication-especially but not exclusively in the field of health-as their professional competence makes the information provided more reliable. Nevertheless, it must be pointed out that the role of experts is very difficult because they deal with phenomena that science can't explain yet. In such a situation, providing information that is necessarily incomplete can provoke extreme reaction from the public (Raoult, 2020).

The magnitude of the current COVID-19 pandemic is comparable to that of another global health crisis called the Spanish flu, which occurred in 1918-1919; its global spread decimated tens of millions of people. Assuming that the objectives of public health communication remain essentially identical, examining how public health communication during the first half of the last century differs from that in the current context is interesting. In particular, this paper aims to highlight the differences in public health communication in France during the two pandemics by analysing a set of contemporary newspaper articles reporting on them, with particular attention to the role of experts.

The paper is divided into three main sections. The first section describes the methodology used and the construction of two corpora: one containing newspaper articles published in 1918-1919 on the Spanish flu and the other consisting of newspaper articles on the COVID-19 pandemic published from December 2019 to June 2020. The following two sections present the results of the analysis aimed at identifying the main characteristics of public health communication in France during the Spanish flu (\$2) and the COVID-19 pandemic (§3), with a focus on the contribution of experts. Finally, the conclusion highlights the major differences in French public health communication during the two crises.

\section{Methodology and construction of the corpora}

The main characteristics of French public health communication at the time of the Spanish flu were observed by analysing the corpus Grippe espagnole; it contains articles on the subject published during the period 1918-1919 in two French newspapers, Le Matin and Le Petit Parisien, which are available online on the Gallica website, the digital library of the BnF-Bibliothèque nationale de France. Le Matin and Le Petit Parisien were chosen because they are two of the four largest French newspapers on the eve of the First World War. At the time, both newspapers were sold in more than a million copies (Allemand \& Oullion, 2005, p. 35). The corpus Grippe espagnole was formed by searching for all articles during the period considered containing the word 'grippe' and then selecting those relating to the flu epidemic. A total of 214 articles were identified, 70 of which were published in $L e$ Petit Parisien and 144 in Le Matin.

Public health communication in France during the current health crisis was examined by analysing articles published from December 2019 to June 2020 in the French newspaper Le Monde. The articles in question are available to subscribing readers in the newspaper's archive, which is equipped with a search engine allowing readers to 
carry out thematic searches. A total of 6,779 articles relating to the COVID-19 pandemic have been identified by searching the keyword 'coronavirus'. To facilitate the analysis, the number of articles was reduced by selecting those containing not only the keyword 'coronavirus' but also the term 'expert', as the focus of the current study is the contribution of experts. A total of 139 articles related to the pandemic were obtained, covering the whole period under examination. In the following phase, the corpus Covid was created, in which 62 articles with the main objective of informing about the coronavirus pandemic were selected from the previous corpus.

As for the texts that have been removed from the corpora because they did not have the Spanish flu or COVID-19 epidemic as their main subject, the following types can be identified:

- advertisements for medicines against the flu, also mentioning the Spanish flu (only in the corpus Grippe espagnole)

- advertisements with offers of medical consultations (only in the corpus Grippe espagnole)

- obituaries (only in the corpus Grippe espagnole)

- articles providing information on the state of health or death of public personalities

- articles containing non-experts' opinions on the pandemic

- other articles whose main topic is not the health crisis but its consequences (e.g. limited services, cancelled events, impact on the economy)

The aim of the analysis of the selected articles is to identify the characteristics of public health communication in France during the two pandemics with the following taken into account:

- the types of articles providing information on the epidemic

- the characteristics of the experts involved

- the type of information provided

\section{Results of the analysis: The case of the Spanish flu}

The analysis of the corpus Grippe espagnole revealed that the Spanish flu epidemic was mentioned for the first time in a short article, L'épidémie de grippe en Espagne [The flu epidemic in Spain], which was published in Le Matin on 30 May 1918. Le Petit Parisien reported the crisis for the first time on 2 July 1918 in the article L'épidémie de Nuremberg. La grippe en plein été [The Nuremberg epidemic. Flu in the middle of summer], calling the epidemic grippe espagnole [Spanish flu]. Let us look at the article from Le Petit Parisien to get an idea of how the emergence of the epidemic was assessed at the time: 


\section{L'épidémie de Nuremberg \\ LA GRIPPE EN PLEIN ÉTÉ \\ Berne 1"r juillet. \\ Le Berliner Tageblatt du 29 soir donne des renseignements sur l'épidémie de grip- pe que l'agence Wolff a signalée à Nurem- berg. \\ Les autorités médicales de Berlín, sou- cieuses de rassurer l'opinion, déclarent que la grippe espagnole qui vient de faire son apparition en Lllemagne n'est pas dan- gereuse. Selon les directeurs de l'institut bactériologique médicale, cette épidémie rappelle celles qui se sont produites dans toute l'Europe entre 1889 et 1893 . Les membres de. I'Institut Koch, qui ont déjầ traité un certain nombre de cas, déclarent que les personnes agées sont moins attein- tes que les jeunes, que la maladie caracté- risée par une forte flèvre et une inflamma- tion des muqueuses évolue en deux ou trois jours. Ils jugent que l'épidémie ne pré- sente aucun danger pour la population. Il n'a pas été constaté de cas mortels.}

Fig. n. 1: The article L'épidémie de Nuremberg. La grippe en plein été published on 2 July 1918 in Le Petit Parisien ${ }^{1}$

The term 'Spanish flu' was attributed to the epidemic because the first reports on its emergence informed about the situation in Spain. However, at the time, it was known that the first outbreak of the epidemic did not occur in Spain. The article La prétendue grippe espagnole viendrait d'Allemagne [The alleged Spanish flu comes from Germany] in 7 July 1918 (Le Petit Parisien) reports that the epidemic started in Germany a few months earlier and denounces how the local authorities managed to hide it. However, the press at the time was unanimous in stating that the name of the epidemic had no particular meaning; it was not a new disease but another flu epidemic with serious consequences:

'Qu'elle soit russe, espagnole, italienne ou allemande, peu importe : elle a fait des ravages et son nom est sans intérêt'. [Whether it (the flu) is Russian, Spanish, Italian or German,

\footnotetext{
${ }^{1}$ The Nuremberg epidemic

Flu in the middle of summer Bern 1st July

On the evening of the 29th, the Berliner Tageblatt informs the public about the flu epidemic, reported by the Wolf Agency in Nuremberg.

Anxious to reassure the public, the medical authorities in Berlin state that the Spanish flu, which has just appeared in Germany, is not dangerous. According to the directors of a medical bacteriological institute, the epidemic is reminiscent of those that occurred throughout Europe between 1889 and 1893. The members of the Koch Institute, who have already treated a number of cases, say that the elderly are less affected than young people and that the disease, characterised by high fever and inflammation of the mucous membranes, develops in two or three days. They consider the epidemic harmless to the population. There have been no fatal cases.
} 
it does not matter: it has wreaked havoc and its name is irrelevant.] (Le Matin, 03/09/1918, the quotation comes from an article published in Le Mercure de France)

'Elle a beau changer de nationalité et prendre des déguisements variés, c'est toujours notre ancienne connaissance l'influenza'. [It (the flu) may change its nationality and take on a variety of disguises, but it's still our old acquaintance: influenza.] (Le Petit Parisien, 09/07/1918)

As for the course of the epidemic in France, according to the article On peut lutter contre la grippe espagnole [We can fight the Spanish flu] published on 26 September 1918 in Le Petit Parisien, the Spanish flu appeared in France in April 1918. The epidemic swept through the country in three waves: from April to August 1918, from September to November 1918 and from February to March 1919 (Bouron, 2009, p. 83). An analysis of the articles in the corpus Grippe espagnole shows that the most serious period of the epidemic in France seems to be the second half of 1918. Looking at the article titles, we can see the variability in the strength of various epidemic waves:

La grippe espagnole a gagné l'Europe. En France, cette influenza est bénigne et elle est guérie en une semaine environ [The Spanish flu has reached Europe. In France, this influenza is harmless and is cured in about a week] (Le Matin, 07/07/1918)

La situation sanitaire est toujours excellente [The health situation is still excellent] (Le Petit Parisien, 18/09/1918)

L'épidémie de grippe. Le nombre des malades a encore augmenté pendant la dernière semaine. Plus que jamais des précautions et des mesures sont nécessaires pour se prémunir contre le fléau [The flu epidemic. The number of sick people has increased again in the last week. Precautions and measures are needed more than ever to protect against this scourge] (Le Matin, 31/10/18)

L'épidémie de grippe va toujours s'atténuant [The flu epidemic is decreasing] (Le Petit Parisien, 09/11/1918)

Recrudescence de la grippe. Quoiqu'elle paraisse légère, prenons des précautions strictes [Recurrence of the flu. Although it may seem mild, let us take strict precautions] (Le Matin, 7/12/1918)

La grippe est en recrudescence à Paris. 900 décès sont attribuables cette semaine à l'épidémie ou à ses complications [Influenza in Paris is on the rise. 900 deaths this week are attributable to the epidemic or its complications] (Le Matin, 23/02/1919)

Sommes-nous débarrassés de la grippe? [Are we free from the flu?] (Le Petit Parisien, 24/10/1919)

The analysis of 214 articles in the corpus Grippe espagnole revealed that in 103 articles, the information is provided by experts. In particular, 34 articles come from Le Petit Parisien and 69 come from Le Matin. The other 111 articles (36 from Le Petit 
Parisien and 75 from Le Matin) provide information on the epidemic without the contribution of experts.

\subsection{Types of articles providing information on the epidemic}

Regarding the articles providing information on the Spanish flu, the following types have been identified:

- articles providing statistical data on the course of the crisis in France (e.g. number of deaths, sick people)

- reportages describing the situation in France and, to a lesser extent, that in other countries

- reportages providing information on the proceedings of the meetings of scientific institutions (Académie de médecine, Académie des sciences), public administration bodies (e.g. city councils) and other institutions dealing with public health (hygiene committees)

- articles providing the results of scientific studies on the Spanish flu

- interviews with experts and public health officials

\section{2 Characteristics of the experts involved}

The experts in the field of health are mainly doctors and scientists (university professors and members of scientific institutions). With a few exceptions (e.g. Professeur Vincent, le savant bactériologiste et maître réputé en épidémiologie, Le Petit Parisien, 26/02/1919), the specialisation of experts is not specified. Very often, these experts in the field of health are members of scientific institutions and professional associations. Amongst scientific institutions, Académie de médecine plays the leading role. In the daily newspaper Le Matin, a special section is often dedicated to the news of this institution. Other scientific institutions whose members inform French society about the development of the epidemic are Académie des sciences and Institut Pasteur. Professional associations include, for example, Société médicale des hôpitaux and Syndicat des médecins de la Seine. In addition, individual cases were found in which the article provided information from a foreign scientific institution, such as the Koch Institute (Germany) and the London School of Hygiene (Great Britain).

The experts in the field of health play an important role in French public health institutions, such as the Epidemics Commission, the High Council of Hygiene, the Departmental Council of Hygiene, the City Council, the Medical Inspection Service and the Naval Health Service. The analysis revealed that health experts also intervene during debates on the Spanish flu in the French Chamber of Deputies. Finally, it should be stressed that the management of the Spanish flu crisis was carried out at two levels-the civilian population level (e.g. Service des épidémies pour la population civile) and the military level (e.g. Service de santé militaire).

\section{3 Type of information provided}

The information provided by the experts mainly concerns the following: 
- the health crisis situation in France (statistics-number of deaths, etc.)

- development of the epidemic in other countries, such as Germany, Switzerland, Spain and England

- comparison of the Spanish flu epidemic with other flu epidemics in the past

- measures taken in France to prevent the spread of the disease

- useful tips to avoid the disease

- the path of the disease, its types and serious complications

- assumptions about the origin of the disease

- information on new treatments for the disease and the discovery of new medicines

\section{Results of the analysis: The case of the COVID-19 pandemic}

In a more globalized context, the Covid-19 pandemic is not only a health crisis, but a phenomenon with a considerable impact on the economy, social system and political situation of the countries concerned. Moreover, the epidemic also has an important scientific dimension. This has been analysed in detail by Jullien (2020). Among the scientific disciplines whose experts play a significant role in crisis management and public health communication, Julien (2020, pp. 287-297) highlights the contribution of epidemiology, molecular biology, genetics and the theory of evolution. Currently, the coronavirus pandemic represents a challenge for scientific institutions in the field of health because they have to react quickly, seeking to answer the major scientific and health questions of today's world. Therefore, the strategic plans of scientific institutions, such as that of the Institut Pasteur (Institut Pasteur, n.d), are developed with the aim of boosting research and increasing its impact on health issues.

During the period from December 2019 to June 2020, the first article providing information on the coronavirus-related disease was published in the newspaper Le Monde on 9 January 2020 under the title Une pneumonie d'origine inconnue en Chine [Pneumonia of an unknown origin in China]. The analysis of the corpus Covid, which contains 62 articles on the pandemic, revealed that in 48 articles, the information is provided by experts. The other 14 articles contain information of various kinds (particularly statistics on deaths and sick people) without the contribution of experts.

\subsection{Types of articles providing information on the epidemic}

The articles informing about the COVID-19 pandemic are of the following types:

- articles providing very precise statistical data on the course of the crisis in France and in other countries around the world

- reportages describing the situation in France and in other countries, also providing testimonies of the local population and of doctors helping in the fight against the virus

- reportages about the proceedings of meetings of certain institutions, particularly those of the World Health Organization 
- articles providing the results of scientific studies on the coronavirus pandemic, including studies conducted abroad

- interviews with experts and public health officials

- $\quad$ articles reporting health experts' opinions on the health crisis

\section{2. Characteristics of the experts involved}

In the management of the COVID-19 pandemic in France, an important role is played by 11 experts who form the Conseil scientifique COVID-19, established on 10 March 2020 with the task of providing relevant information to the French President. In managing the crisis, the French government is also supported by experts from the Haut Conseil de la santé publique (Zanola, 2020, p. 86). As regards the corpus Covid, the analysis revealed a wide variety of health experts providing the public with information on the pandemic. The specialisation of doctors (general practitioner, pathologist, neurologist, resuscitation doctor, etc.) is usually specified as well as that of the scientists consulted (immunologist, virologist, infectiologist, microbiologist, professor of emergency medicine, professor of public health, infectious disease expert, bioengineer, epidemiologist, professor of chemical biology, etc.). The health experts who provide information to the public are members of French scientific institutions (especially Académie nationale de médecine, L'Inserm - Institut national de la santé et de la recherche médicale, Institut Pasteur) and several foreign scientific institutions (e.g. Chinese Centre for Disease Control and Prevention, German Hospital Federation and London School of Hygiene and Tropical Medicine). The analysis also showed that alongside health and biology experts, experts from other domains, such as anthropology, sociology and mathematics, also play an important role in crisis management and public information dissemination.

\section{3 Type of information provided}

The types of information provided in the articles on the COVID-19 pandemic broadly correspond to those found in the articles about the Spanish flu. Compared with the corpus Grippe espagnole, the corpus Covid does not include articles comparing the coronavirus pandemic with previous influenza epidemics. The statistics on the course of the epidemic (number of deaths, sick people, etc.) are very precise and concern France and other countries. More often, scientists deal with the question of the origin of the virus. Many articles also contain the reflections of experts on the likely course of the pandemic and on life in the future after the virus. Attention should be given to articles aiming to disprove fake news about the origin of the virus, such as the following:

Non, cette vidéo virale ne prouve pas que le coronavirus est une " arme biologique militaire » [No, this viral video does not prove that the coronavirus is a 'military bioweapon'] (Le Monde, 18/03/2020). 


\section{Conclusion}

The differences in French public health communication during the two pandemics separated by 100 years are mainly due to their different political contexts, technology developments and increased globalisation. Whereas in the years 1918-1919, the newspapers Le Petit Parisien and Le Matin were published in paper form and with a reduced number of pages (4), the newspaper Le Monde has many more pages and is also published in digital version. For this reason, more articles report on the COVID19 pandemic than on the Spanish flu. It should also be noted that in the years 19181919 , events related to the end of the First World War were the focus of attention, placing less emphasis on news about the Spanish flu epidemic. Indeed, a recent study aimed at analysing the Parisian press during the Spanish flu has shown that in almost all cases, articles on the flu epidemic are published inside the newspaper and not on the front page (Bar-Hen \& Zylberman, 2015, p. 35).

During the two pandemics, experts play a significant role in providing reliable information on the situation and explaining to the public the necessity of the measures taken by the authorities-measures which restrict the freedom of the people (Baverez, 2020) but help reduce the spread of the disease. In the case of the Spanish flu, public health communication takes place almost exclusively in France; the data, which are provided by French experts, focus on the situation in the country. The national character of the management of this health crisis is also reflected in the fact that the term 'pandémie' is never used in the articles of the corpus Grippe espagnole. On the other hand, the information provided during the current COVID-19 pandemic, as well as the management of this crisis, has a more global character. The French public is provided with information not only on the development of the epidemic in France but also on the health situation worldwide. The experts providing information on the pandemic come from different scientific institutions around the world, and compared with the experts in 1918-1919, they have a wide variety of specialisations. Moreover, the analysis of the corpus Covid revealed that the main reference institution for pandemic information is no longer a French institution (such as Académie de médecine during the Spanish flu) but the World Health Organization, which was founded in 1948 (Organisation mondiale de la Santé, 2020). It should be also noted that after 100 years, the perception of experts has changed, especially because the figure of an unreliable expert, who spreads false information about the pandemic, is now much more visible. Therefore, in the current context of the coronavirus pandemic, public health communication and real experts also have the task of helping the public interpret properly the large amount of information provided, especially by identifying and disproving fake news. Finally, the analysis revealed that in public health communication, an important role is played by scientific institutions. That's why in order to contribute effectively to crisis management, scientific institutions should be more and more committed to communicating research results to the public in a clear and appropriate way. 


\section{References}

[1] Allemand, L. \& Oullion, J.-M. (2005). Les grandes questions des médias: enjeux et stratégies des médias contemporains. Paris, France: L'Etudiant.

[2] Bar-Hen, A. \& Zylberman, P. (2015). La presse parisienne et la grippe "espagnole" (1918-1920). Les Tribunes de la santé, 47(2), 35-49. Retrieved from https://www.cairn.info/revue-les-tribunes-de-la-sante1-2015-2page-35.htm

[3] Baverez, N. (2020). Les libertés au temps du coronavirus. Commentaire, 170(2), 265 -270. Retrieved from https://www.cairn.info/revuecommentaire-2020-2-page-265.htm

[4] Bouron, F. (2009). La grippe espagnole (1918-1919) dans les journaux français. Guerres mondiales et conflits contemporains, 233(1), 83-91. Retrieved from https://www.cairn.info/revue-guerres-mondiales-etconflits-contemporains-2009-1-page-83.htm

[5] Gallica. (n.d.). Le Matin. Retrieved from https://gallica.bnf.fr/ark:/12148/cb328123058/date1918

[6] Gallica. (n.d.). Le Petit Parisien. Retrieved from https://gallica.bnf.fr/ark:/12148/cb34419111x/date1918.r=

[7] Institut Pasteur. (n.d.). Institut Pasteur - Plan stratégique 2019-2023. [Brochure]. Retrieved from https://www.pasteur.fr/fr/file/22768/download

[8] Jullien, V. (2020). Ce que peuvent les sciences. Paris, France: Editions Matériologiques.

[9] Le Monde. (n.d.). Les archives du Monde. Retrieved from https://www.lemonde.fr/archives-du-monde/

[10] Organisation mondiale de la Santé (2020). Qui sommes-nous. Retrieved from https://www.who.int/fr/about/who-we-are

[11] Raoult, D. (2020). Épidémies : vrais dangers et fausses alertes. De la grippe aviaire au Covid-19. Neuillysur-Seine, France: Michel Lafon.

[12]Zanola, M. T. (2020). Le parole della pandemia in Francia: il dialogo di una società. In M. Scaglioni \& M. Sala (Eds.), L'altro virus. Comunicazione e disinformazione al tempo del COVID-19 (pp. 85-94). Milano, Italy: Vita e pensiero. 